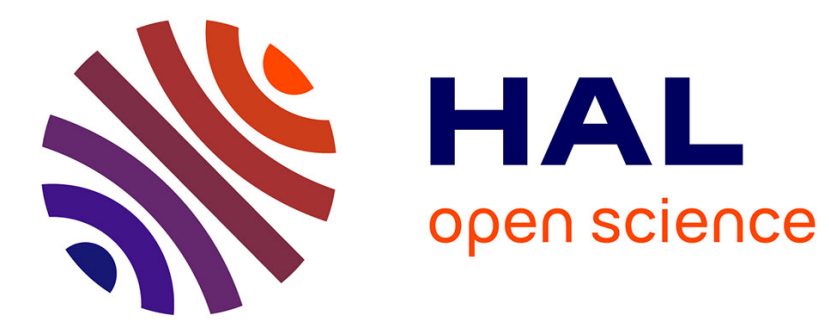

\title{
Experiences from Assistive Technology Services and Their Delivery in Finland
}

Anne-Marie Tuikka, Neeraj Sachdeva

\section{To cite this version:}

Anne-Marie Tuikka, Neeraj Sachdeva. Experiences from Assistive Technology Services and Their Delivery in Finland. 16th Conference on e-Business, e-Services and e-Society (I3E), Nov 2017, Delhi, India. pp.16-22, 10.1007/978-3-319-68557-1_2 . hal-01768520

\section{HAL Id: hal-01768520 \\ https://hal.inria.fr/hal-01768520}

Submitted on 17 Apr 2018

HAL is a multi-disciplinary open access archive for the deposit and dissemination of scientific research documents, whether they are published or not. The documents may come from teaching and research institutions in France or abroad, or from public or private research centers.
L'archive ouverte pluridisciplinaire HAL, est destinée au dépôt et à la diffusion de documents scientifiques de niveau recherche, publiés ou non, émanant des établissements d'enseignement et de recherche français ou étrangers, des laboratoires publics ou privés. 


\title{
Experiences from assistive technology services and their delivery in Finland
}

\author{
Anne-Marie Tuikka \\ Neeraj Sachdeva
}

\begin{abstract}
The purpose of this article is to understand and document the level and quality of assistive technology (AT) driven rehabilitative support offered to people with impairments within Finland. Availability, accessibility and adoption of assistive technologies are of interest to this study. Currently public institutions, such as city hospitals and national social security institution, offer AT services generally on the basis of age, employment and individual needs. The main research question is, how people with impairments and their relatives perceive assistive technology delivery, use as well as continued adoption? Based on data, the different aspects of AT service delivery model and its relationship to rehabilitation process are described.
\end{abstract}

The empirical data is gathered through interviews and official documents including appropriate laws and guidelines published by public institutions. Analysis of the data highlights stages within the current system where negative experiences create distrust and dissatisfaction among AT adopters. These experiences are categorized to themes and stages which may be used for analyzing AT services and its relation to rehabilitation in future research. Further research would be needed to compare the applicability of the defined stages in analyzing delivering AT services in other countries - both similar and different to Finland.

Keywords: assistive technology, service delivery model, Finland, visual impairments, the autism spectrum

\section{Introduction}

People with impairments have found numerous uses for technologies in their lives helping them live a normal life, regardless of their impairments. Often, technologies that "assist" in improving quality of life, especially for the people with impairments, are classified as "assistive technologies" (AT). Hersh [4] has defined the role of assistive technology in terms of social model as "overcoming the gap between what disabled people want to do and what the existing social infrastructure allows them to do". AT for people with severe visual impairments include screen and braille readers, walking 
sticks for navigation and hearing aids; whereas AT for people with neurobiological impairments (such as the autism spectrum) include electronic communication aids, communication books and function cards. However, knowing about, obtaining and continually using these technologies is usually not as simple as walking into an Apple store and ordering a new device. Many devices don't have built-in assistance modules (as cited in Hitchcock \& Stahl [5]), which necessitates purchase and use of an additional technologies. Even though some communication applications can be accessed through Apple store, they are usually expensive and they often lack translation to smaller language groups such as Finnish or Swedish (both official languages of Finland).

This article presents preliminary results from an ongoing research project, which concentrates on studying the assistive technology service delivery model in Finland and experiences related to it. In this article, various assistive and rehabilitation technology service delivery models are evaluated to recognize current state of Finnish assistive technology service delivery model (later referred as AT service delivery model). Adya et al. [1] have previously analyzed different AT service delivery models, focusing on charity-based, community-based rehabilitation, individual empowerment, entrepreneurial, globalization and universal design model. Bartfai and Boman [2] have analyzed policies concerning AT and home modification services for impaired people in Sweden. The Finnish AT service delivery model - slightly different to previously mentioned models - is analyzed through empirical data which is collected as a part of this research project.

The main research question is, how people with impairments and their relatives perceive assistive technology delivery, use, and continued adoption? To answer to this question, three sets of stakeholders are interviewed - people with impairments who need and use assistive technology, parents of children with impairments, and service providers who recommend and provide assistive technology and relevant training. The semi-structured interviews focus on the experiences of accessing, applying and using assistive technology; before, during and after the rehabilitation process. At this point of the project, total amount of interviews and interviewees is ten. Most of the interviews were done face-to-face $(n=9)$ and one of them was done through phone.

In following section, we describe the context of delivering AT services in Finland. Then we continue by analyzing the experiences of Finnish assistive technology users, their parents and the professionals. We finish with the discussion about the future of Finnish AT service delivery model and its requirements in different stages of disability.

\section{Assistive technology service delivery model in Finland}

There are multiple AT service delivery models in Finland. Central to all the models is the main principle that a person should be able to get any assistive technology which is prescribed to them, for free. The AT and the training related to its use are paid by different organization in different cases.

In general, city is responsible for offering or covering the cost of AT for its citizen if AT is used for medical rehabilitation. This can be understood from the law on health care [8] which states that city is in charge of organizing medical rehabilitation for its 
citizens, when their rehabilitation is not covered by the national social security institution named as KELA. For this reason, city needs to organize AT for any person who is under the age of 13 or a person over 65 years, because their medical rehabilitation is never covered by KELA. In the case of the person who is 13 to 65 years old, KELA is responsible for covering the cost of the assistive technology which is needed to maintain person's abilities to work and to study [6,9]. In the case of someone who has got impaired as a consequence of work accident, travel accident or another kind of accident covered by the private insurance, the private insurance company should pay for the prescribed assistive technology and the training related to it.

When city is responsible for organizing AT for its citizens, citizen usually has a possibility to get the AT through public hospital which is funded by the city or sometimes by multiple cities within same geographical area. To get the assistive technology, the patient needs to have prescription for certain kind of assistive technology from the doctor who is responsible for their rehabilitation. However, the final decision about the specific type of assistive technology such as certain device or particular application is often done by the professionals working in the unit which is specialized on AT services. Most often the assistive technology is loaned to the person who needs it. However, the loaning time may be so long that the assistive technology is never transferred to anyone else after it is returned. In these cases, the assistive technology is practically given to the person who needs it.

In the case of KELA, the process is quite different. To get KELA to support the cost of the assistive technology, the person needs to have prescription from a doctor to show that they need this technology for their medical rehabilitation. After receiving the prescription, they can apply funding from KELA. After they have received the positive decision from KELA, they can buy the technology and KELA will refund the purchase amount to them. In some cases, KELA can decide not cover the full cost of the technology because the person chose a technology which is too expensive compared with the technology which would have satisfied the requirements of their medical rehabilitation.

All of the previously mentioned cases focus on medical rehabilitation. In the case of AT which is not needed for medical rehabilitation, it is possible to get financial support from the social services within a certain city or a municipality. This type of AT might be covered if they are needed for free time activities or to support independent living. However, only half of the cost of the AT is covered by social services. The other half must be covered by the person who needs the technology. [9]

\section{Stakeholder perspectives}

This section shares perspectives on stakeholders' experience with assistive technology service delivery in Finland. These stakeholders include AT users who have sever visual impairment, parents of children within the autism spectrum and service providers. Some of the service providers are also visually impaired, and regular users of assistive technologies. The experiences of different stakeholder groups have been grouped based 
on three themes commonly identified in the data. These themes are availability, accessibility and adoption of AT. Availability refers to the knowledge about different technologies and services related to them. Accessibility refers to a person's possibilities to get the AT they need. Adoption refers to communication between service providers and the experiences from continued usage of AT. Each perspective is further classified as either positive, neutral or negative experience.

\section{On availability:}

Representatives of different stakeholder groups appear to disagree whether there is enough information about the AT services. It seems, that AT availability can be improved by making more resources and opportunities for AT education available. Here is what the participants had to say:

"There should be some resource/forum for blind people. E.g. the magazine for the blind association - it could have section about new technologies." - Legally blind assistive technology user 1 , negative experience

"...the people in the rehabilitation group, they know exactly what they have (in reference to assistive technologies available)." - Service provider 4, positive experience

Finland is quite far ahead in terms of technology availability. But, there are restrictions. It's easier to get these technologies if you have a job or are studying. - Service provider 5, positive experience

\section{On accessibility:}

Most people with impairments first learn about ways to access AT via a professional who offers more insights into what's accessible. In some cases, bureaucracy (and other factors) can be an impediment to assistive technology access, as shared here:

"2-3 different types of screen readers were available in the market. JAWS was a good choice, but it was not possible to buy, as it was expensive and I had to get reimbursement and permission from KELA or insurance company, which could take 2 months." - Legally blind assistive technology user 1, negative experience

"I don't think it (assistive technology design) is a question of attitude. I think they (designers and developers) don't know that there are also other groups that can't use them (assistive technology) the same way as normal users use them." - Legally blind assistive technology user 2 , neutral experience

"If you have workplace or are studying at university, it's easy to get it (screen readers), otherwise it's not so easy." - Service Provider 3, negative experience

"The speak therapist (who is caring for the child and is a private entrepreneur) told us about the devices. She recommended them to the recommending therapist (who works in the city). Naturally, the process is really complicated." - Parent 1, negative experience. 


\section{On adoption:}

Positive adoption and continued use is often the end goal of any assistive technology service. For this reason, there are IT trainers and installers for visually impaired people who need AT. We have interviewed one of them (Service Provider 1), who is the only Linux trainer in Finland, and therefore has customers from (different) parts of Finland. There is also portal related to accessibility, although, it "has been a little bit quiet" according to Service Provider 2, who is responsible for maintaining it.

The parents of children within the autism spectrum have got the training for their child's AT through public hospital, which has special unit focusing on AT services. Parent 1 had been very happy with their services whereas Parent 2 had faced problems when their AT got broken. She said: "It was a device which should not have got broken if the child is observed when using it. For this reason, we should have written a report to explain, how it got broken."

Experiences from the adoption of AT were generally positive, as stated here:

"He trained with the speak therapist. He trained with us. He is now hundred times better with the device than me or his father." - Parent 1, positive experience

"The screen reader is gives me independence in general tasks. You get access to internet and you can pay your bills in the bank or do just anything you want without help from someone else." - Service Provider 3, positive experience

\section{Discussion}

Analysis of data highlights the three themes - availability, accessibility and adoption (Figure 1) - which affect the delivery of assistive technologies and services (e.g. training) related to them. Availability affects people regardless of where they live. Accessibility pertains individually to people and is impacted by their ability to access an assistive technology. Finally, adoption refers to the frequency and continuity of assistive technology use, and can be impacted by quality of the technology and associated training. Each theme has a common element - interaction - between the stakeholders. In this scenario stakeholders include people, who need AT, care givers of people, who need AT, and people who provide AT and services related to it.

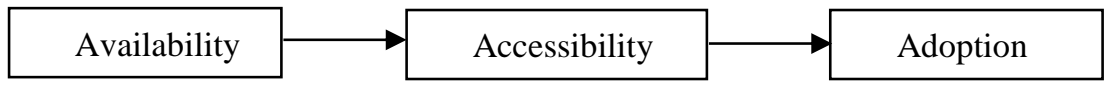

Figure 1: Themes of Assistive Technology Service Delivery

Negative experiences can generally create distrust and dissatisfaction among technology adopters, which can create further negative impact on consumption decisions $[3,7]$. While the interviews did not highlight any exclusive distrust or dissatisfaction, the interviewees were apprehensive of using new technology unless they had thoroughly reviewed it, or it had been strongly recommended by someone else. This is contradictory behavior when compared with the technology adoption generally visible in the modern world of annual cycle of new iPhones and operating systems. If type of 
behavior could be detected among other users of AT in different contexts, it might be possible to deduce that people with impairments and their parents generally need bigger time investment with assistive technologies, and hence prefer to access and adopt assistive technology as and when they need - and not when it becomes available.

Based on the interviews, a clearer insight into the delivery cycles of assistive technology services was obtained, and it can be classified into three stages:

Pre-Disability: In instances where a person is expected to face one or the other form of disability, they should be offered enough information and education on what to expect. Ideally, this person should be able to consult with doctors and prepare for an easier transition post-disability, and ensure that they can continue living similar or even better quality of life. However, due to somewhat untimely nature of some disabilities, this might not apply in each case.

Immediately Post-Disability: During this stage, it is crucial to enable a person to receive easy access to AT. For example, someone who has just lost vision should be offered immediate support to purchase a screen reader or braille reader.

Support Post-Disability: Continued support for older and newer technologies and services is essential to keep adoption rate high as well as continue a level of comfort.

\section{Conclusion}

The Finnish society provides a rich level of assistive technology based rehabilitation to those that need it. This research project has started to study the experiences of different stakeholders on the accessibility, availability and adoption of AT in Finland. However, the current study is limited by the small number of representatives, who have been interviewed. Further interviews with people with impairments, their parents and service providers dealing with different impairments at different stages of AT lifecycle could offer more insights and further develop the three themes - availability, accessibility and adoption - to create a solid framework which could be employed to different contexts. Future research on the assistive technology service delivery model in the Finnish context is also needed, because the governance of health care and social care services are changing in Finland. How these changes affect the Finnish assistive technology service delivery model, remains to be seen.

\section{References}

1. Adya, Meera, Deepti Samant, Marcia J. Scherer, Mary Killeen, and Mi-chael W. Morris. "Assistive/Rehabilitation Technology, Disability, and Service Delivery Models." Cognitive Processing 13 Suppl 1 (August 2012): S75-78. doi:10.1007/s10339-012-0466-8.

2. Bartfai, Aniko, and Inga-Lill Boman. "Policies Concerning Assistive Technology and Home Modification Services for People with Physical and Cognitive Disabilities in Sweden.” NeuroRehabilitation 28, no. 3 (2011): 303-8. doi:10.3233/NRE-2011-0658.

3. Frankoff, Denise J. "Experiences of Families Seeking Funding for Assistive Technologies for Children with Disabilities: Awareness of Legal Mandates.” In Efficacy of Assistive 
Technology Interventions, 1:229-58. Advances in Special Education Technology 1. Emerald Group Publishing Limited, 2015. doi:10.1108/S2056-769320150000001009.

4. Hersh, Marion, and Johnson, Michael A. Assistive Technology for Visually Impaired and Blind People | Springer. Accessed April 26, 2017. http://www.springer.com/gp/book/9781846288661.

5. Hitchcock, Chuck, and Skip Stahl. "Assistive Technology, Universal De-sign, Universal Design for Learning: Improved Learning Opportunities.” Journal of Special Education Technology 18, no. 4 (September 1, 2003): 45-52. doi:10.1177/016264340301800404.

6. KELA. Vaativa lääkinnällinen kuntoutus ja palvelut. Available electronically http://www.kela.fi/vaativan-laakinnallisen-kuntoutuksen-palvelut. Last accessed 30.4.2017.

7. Ou, Carol Xiaojuan, and Choon Ling Sia. "Consumer Trust and Distrust: An Issue of Website Design.” International Journal of Human-Computer Studies 68, no. 12 (December 2010): 913-34. doi:10.1016/j.ijhcs.2010.08.003.

8. Terveydenhuoltolaki 30.12.2010/1326. Section 3, 29 §. Available electronically http://www.finlex.fi/fi/laki/ajantasa/2010/20101326?search[type]=pika\&search[pika]=terveydenhuoltolaki\#L3P29. Last accessed 30.4.2017.

9. THL. Apuvälinepalvelujen työnjako. In Vammaispalvelujen käsikirja. Available electronically https://www.thl.fi/fi/web/vammaispalvelujen-kasikirja/itsenaisen-elaman-tuki/apuvalineet/apuvalinepalvelujen-tyonjako. Last accessed 30.4.2017. 